\title{
Upcoming Events in Pediatric Cardiology 41-7
}

(c) Springer Science+Business Media, LLC, part of Springer Nature 2020

Please note that due to Covid-19 pandemic, many meetings are being held virtually. Please check organization websites for details.

October 2-5, 2020

American Academy of pediatrics National Conference Virtual meeting

https://www.aapexperience.org/

November 13-17, 2020

Scientific Session, American Heart Association Virtual meeting

https://professional.heart.org

January 30-February 2, 2021

Annual Meeting of the Society of Thoracic Surgery

Austin, Texas, USA-Check to see if meeting will be changed to a virtual one

https://www.sts.org

March 20-22, 2021

American College of Cardiology, Annual Scientific Session

Atlanta, Georgia, USA-Check to see if meeting will be changed to a virtual one

https://www.acc.org
May 1-4, 2021

American Association of Thoracic Surgery, Annual Meeting

Seattle, Washington, USA - Check to see if meeting will be changed to a virtual one

https://www.aats.org

June 18-21, 2021

American Society of Echocardiography, Annual Scientific Sessions

Boston, Massachusetts, USA — Check to see if meeting will be changed to a virtual one

https://www.asecho.org

September 2021 (check website for exact dates)

Pediatric Interventional Cardiology Symposium-AICS

Check website for location

https://www.picsymposium.com/

Publisher's Note Springer Nature remains neutral with regard to jurisdictional claims in published maps and institutional affiliations. 